\title{
Sexual Prejudice in the Portuguese Political Context
}

\author{
Maria Ferros ${ }^{1}$ and Henrique Pereira ${ }^{1,2,3, *(D)}$ \\ 1 Department of Psychology and Education, Faculty of Social and Human Sciences, University of Beira Interior, \\ Pólo IV, 6200-209 Covilhã, Portugal; maria.ferros@ubi.pt \\ 2 Health Sciences Research Centre (CICS-UBI), 6200-506 Covilhã, Portugal \\ 3 Research Centre in Sports Sciences, Health Sciences and Human Development (CIDESD), \\ 5001-801 Vila Real, Portugal \\ * Correspondence: hpereira@ubi.pt
}

\section{check for}

updates

Citation: Ferros, Maria, and Henrique Pereira. 2021. Sexual Prejudice in the Portuguese Political Context. Social Sciences 10: 56. https://doi.org/10.3390/socsci 10020056

Academic Editor: Dawn M. Baunach Received: 19 November 2020

Accepted: 2 February 2021

Published: 6 February 2021

Publisher's Note: MDPI stays neutral with regard to jurisdictional claims in published maps and institutional affiliations.

Copyright: (c) 2021 by the authors. Licensee MDPI, Basel, Switzerland. This article is an open access article distributed under the terms and conditions of the Creative Commons Attribution (CC BY) license (https:/ / creativecommons.org/licenses/by/ $4.0 /)$.

\begin{abstract}
Sexual prejudice is a negative attitude toward an individual due to their belonging to a group defined by sexual minority behaviors, attractions, or orientations. As no studies assessing sexual prejudice levels among self-identified politicians have been conducted in Portugal, this study was carried out to address this gap in the literature. In addition, we sought to compare differences in levels of sexual prejudice by gender, religiosity, and political orientation. The sample consisted of 302 self-identified active politicians in Portugal, of whom 157 were men (52\%) and 145 were women $(48 \%)$, with an average age of 45.98 years. Study measurement instruments included a sociodemographic questionnaire and the Sexual Prejudice Scale in the Portuguese Political Context. Participants responded to this study's outreach online, and they received emails that referred them directly to the online survey. The principal results show that, despite moderate overall levels of sexual prejudice among the sample, men and participants with right-wing general, social, and fiscal political views demonstrated significantly higher sexual prejudice scores. Negative levels of political engagement and negative attitudes toward lesbians and gay men were significant predictors of sexual prejudice. It is very important to raise awareness of this phenomenon among both politicians and the general public, so that it can be addressed accordingly.
\end{abstract}

Keywords: sexual prejudice; homophobia; heterosexism; political psychology; political context; Portugal

\section{Introduction}

Sexual minorities frequently experience violence, discrimination, and personal rejection (Herek 2000b), since minority genders and sexual orientations have often been associated with controversy, stigma, and confusion (Huffaker and Kwon 2016). In order to facilitate research about anti-lesbian, gay, and bisexual (LGB) attitudes, Herek and McLemore (2013) proposed the construct of sexual prejudice, which can be understood as a negative attitude toward an individual due to their belonging to a group defined by minority sexual behaviors, attractions, or orientations. Sexual prejudice is a prevalent phenomenon in our society and research into this topic has been of interest to social scientists since the 1970s (Herek 2000b). It is a broad concept that includes homophobia, homonegativity, heterosexism, and, more recently, transphobia and biphobia (Baiocco et al. 2018).

Despite a societal evolution toward greater acceptance of individuals with diverse sexual experiences, prejudice and discrimination against sexual minorities is still a global social problem (Baunach 2012), given that sexual prejudice is still supported by social norms in various contexts and that social stigma still remains in many cultural institutions, including in political contexts (Hoyt and Parry 2018). Therefore, structural sexual stigma, or heterosexism, is an ideology embedded in institutional practices that puts sexual minority groups at a disadvantage (Herek et al. 2009).

Regarding the social and political environment, in recent decades, lesbian, gay, bisexual, and transgender (LGBT) communities have been gaining increasingly relevant 
importance, not only by claiming their civil rights, but also in fighting against discrimination and in favor of equality (Almeida 2010). Since the end of the 20th century, many countries have made legislative changes to enhance sexual minority protections, especially in the areas of health, employment, and housing, in addition to several major advances in family rights (Carroll and Mendos 2017). For example, Portugal has experienced a series of significant changes over the last four decades, following the Carnation Revolution and the ratification of the democratic Portuguese Constitution of 1976, namely, the expansion of civil and social rights, especially regarding gender equality (Lopes et al. 2016).

In Portugal, homosexuality was considered a crime until it was removed from the Portuguese penal code in 1982. Portugal's accession to the European Union in 1986 proved to be fundamental to the promulgation of multiple pro-equality policies that were later implemented. The main legal mechanism that triggered these changes involved the introduction of a sexual orientation clause that provided explicit constitutional protections against discrimination. The implementation of these protections was subsequently followed by the introduction of a law that permitted de facto same-sex civil unions in 2001, a 2010 law allowing for same-sex marriage, and a gender identity recognition law that was passed in 2011 (Lopes et al. 2016). In addition, laws allowing same-sex couples to adopt and jointly adopt children and permitting access to in vitro fertilization (Costa and Salinas-Quiroz 2019), respectively, were passed in 2016. Notwithstanding, a heterosexist climate still exists in Portugal, creating contradictory social dynamics between legal regulations that stipulate equality and the discriminatory practices still common in daily life (Carneiro and Menezes 2007).

In the most recent Portuguese legislative elections in 2019, a positive economic outlook created a space for the emergence of a greater variety of issues on the political agenda. This new space for debate encompassed not only the less positive aspects of the economic recovery and financial stabilization measures (such as low-quality public services and an increase in foreigners in the labor market), but also issues such as environmental sustainability, taxes, immigration, corruption, and the rights of sexual minorities, among others (Fernandes and Magalhães 2020). Thus, attitudes toward sexual minority identities may have improved, as reflected by the more diverse and inclusive composition of the current Portuguese parliament, which has several members who are women of color, as well as several openly gay or lesbian deputies.

The literature shows that some important variables may influence negative attitudes toward LGB people, such as sociodemographic and psychological characteristics, like gender, as men usually display greater sexual prejudice than women (Brown and Henriquez 2008; Costa et al. 2014; Costa et al. 2018). Age is another variable that may influence negative attitudes toward LGB people (Costa et al. 2014; Schwartz 2010), as older people tend to present higher levels of sexual prejudice when compared to younger people (Avery et al. 2007; Lewis 2003), which can be partially explained by the fact that social attitudes are formed at younger ages and are subsequentially resistant to change, causing older people to retain more conservative attitudes typical of past social norms (Andersen and Fetner 2008). Sexual orientation also could affect attitudes regarding LGB people (heterosexual people typically present more negative attitudes toward LGB people) (Costa and Davies 2012), as could religiosity (Brown and Henriquez 2008; Schwartz 2010) (religious individuals express more negative attitudes toward LGB individuals) (Olson et al. 2006; Whitley 2009). Educational attainment also might impact perceptions of LGB individuals (individuals, with lower levels of educational attainment tending to have higher levels of sexual prejudice) (Schwartz 2010), in addition to cultural differences and ideological beliefs concerning homosexuality (Costa et al. 2014), as well as political orientation (individuals who identified themselves as conservatives present more sexual prejudice than individuals who identify themselves as liberals) (Barth and Parry 2009; Haslam and Levy 2006). Therefore, all of these variables may not solely influence attitudes toward LGB people (Poteat and Mereish 2012), but also the perception of the legitimation of their fundamental rights, including same-sex marriage and parenting (Brumbaugh et al. 2008; Webb and Chonody 2014; Wood and Bartkowski 2004). 
Sexual prejudice is often apparent in some political arguments against LGB rights, which are usually grounded in religious beliefs, conservative political opinions, and/or the desire to protect traditional values (Burridge 2004; Brewer and Wilcox 2005; Miceli 2005; Olson et al. 2006). Thus, public opinion plays a role in the evolution of the rights of sexual minorities, since it can influence which politicians they vote for, and this partially determines the quality of the environment in which sexual minorities live, which can simultaneously be a source of stress and rejection and support and legitimation (Lax and Phillips 2009). Beyond this intrinsic importance, assessing the sexual prejudices of Portuguese politicians can contribute to a broader understanding of the dynamics of politics, power, social movements, public opinion, and policymaking institutions.

Hence, the present study is a pioneer in the Portuguese context, due to its novel main objective that aims to evaluate sexual prejudice levels among a Portuguese political sample. Furthermore, this study also seeks to understand the relationship among several sociodemographic variables and sexual prejudice levels.

\section{Methods}

\subsection{Participants}

The sample consisted of 302 participants who self-identified as active politicians in Portugal, of whom 157 were men (52\%) and 145 were women (48\%), with an average age of 45.98 years. In total, $95 \%$ of the sample self-identified as heterosexual, $2 \%$ as bisexual, and $3 \%$ as homosexual (gay/lesbian). Regarding participants' level of political interest, 59.6\% of the sample claimed to have a substantial level of political interest, and $70.4 \%$ mentioned belonging to a political party or political group. Concerning religion, $68.8 \%$ of participants claimed to be religious, and $53.3 \%$ attributed moderate importance to their religious beliefs. Table 1 shows the sociodemographic characteristics of the sample in greater detail.

Table 1. Sociodemographic characteristics.

\begin{tabular}{|c|c|c|c|c|}
\hline Variables & $\mathbf{n}$ & $\%$ & $\begin{array}{c}M \\
(\min -\max )\end{array}$ & $S D$ \\
\hline Age & & & $\begin{array}{c}45.98 \\
(19-79)\end{array}$ & 10.15 \\
\hline \multicolumn{5}{|l|}{ Gender } \\
\hline Male & 157 & 52 & & \\
\hline Female & 145 & 48 & & \\
\hline \multicolumn{5}{|l|}{ Sexual Orientation } \\
\hline Heterosexual & 284 & 95.0 & & \\
\hline Bisexual & 6 & 2.0 & & \\
\hline Homosexual (Gay/Lesbian) & 9 & 3.0 & & \\
\hline \multicolumn{5}{|l|}{ Ethnicity } \\
\hline White & 275 & 91.4 & & \\
\hline Black/African/etc. & 4 & 1.3 & & \\
\hline Hispanic or Latino & 17 & 5.6 & & \\
\hline Asian & 1 & 0.3 & & \\
\hline Other & 4 & 1.3 & & \\
\hline \multicolumn{5}{|l|}{ Educational Attainment } \\
\hline Primary Education (up to the 9th grade) & 5 & 1.7 & & \\
\hline Secondary Education/High School (up to the 12th grade) & 60 & 19.9 & & \\
\hline Undergraduate Degree & 123 & 40.7 & & \\
\hline Graduate Degree or Program & 99 & 32.8 & & \\
\hline $\mathrm{PhD}$ & 12 & 4.0 & & \\
\hline Other & 3 & 1.0 & & \\
\hline \multicolumn{5}{|l|}{ Socioeconomic Status } \\
\hline Low & 27 & 8.9 & & \\
\hline Medium & 246 & 81.5 & & \\
\hline High & 28 & 9.3 & & \\
\hline Very High & 1 & 0.3 & & \\
\hline
\end{tabular}


Table 1. Cont.

\begin{tabular}{|c|c|c|c|c|}
\hline Variables & $\mathbf{n}$ & $\%$ & $\begin{array}{c}M \\
(\min -\max )\end{array}$ & $S D$ \\
\hline \multicolumn{5}{|l|}{ Professional Status } \\
\hline Employed & 279 & 92.4 & & \\
\hline Unemployed & 7 & 2.3 & & \\
\hline Retired & 15 & 5.0 & & \\
\hline Permanently Disabled & 1 & 0.3 & & \\
\hline \multicolumn{5}{|l|}{ Political Parties } \\
\hline Portuguese Communist Party (PCP) & 6 & 3.0 & & \\
\hline CDU-United Democratic Coalition (PCP-PEV) & 2 & 1.0 & & \\
\hline Ecologist Party “The Greens” (PEV) & 5 & 2.5 & & \\
\hline Left Bloc (BE) & 10 & 4.9 & & \\
\hline Socialist Party (PS) & 96 & 47.3 & & \\
\hline Socialist Youth (JS) & 2 & 1.0 & & \\
\hline People-Animals-Nature (PAN) & 2 & 1.0 & & \\
\hline FREE(L) & 5 & 2.5 & & \\
\hline Together for the People (JPP) & 1 & 0.5 & & \\
\hline CDS-PP & 5 & 2.5 & & \\
\hline Social Democratic Party (PPD/PSD) & 56 & 27.6 & & \\
\hline Portugal Ahead-PSD/CDS-PP Coalition & 1 & 0.5 & & \\
\hline Rise UP! (E) & 1 & 0.5 & & \\
\hline Independent Political Movements & 11 & 5.4 & & \\
\hline \multicolumn{5}{|l|}{ Political Interest Level } \\
\hline None & 5 & 1.7 & & \\
\hline Little & 21 & 7.0 & & \\
\hline Moderate & 96 & 31.8 & & \\
\hline Substantial & 180 & 59.6 & & \\
\hline \multicolumn{5}{|l|}{ Political Commitment } \\
\hline None & 15 & 5.0 & & \\
\hline Little & 23 & 7.6 & & \\
\hline Moderate & 83 & 27.6 & & \\
\hline Substantial & 180 & 59.8 & & \\
\hline \multicolumn{5}{|l|}{ Belongs to a Political Group/Organization } \\
\hline Yes & 212 & 70.4 & & \\
\hline No & 89 & 29.6 & & \\
\hline \multicolumn{5}{|l|}{ Political Position Held } \\
\hline Local Government (Civil Parishes and Municipalities) & 168 & 81.6 & & \\
\hline Central Government & 22 & 10.7 & & \\
\hline Activist & 15 & 7.3 & & \\
\hline None & 1 & 0.5 & & \\
\hline \multicolumn{5}{|l|}{ General Political Views } \\
\hline Liberal Left & 26 & 8.7 & & \\
\hline Left & 49 & 16.3 & & \\
\hline Center-Left & 85 & 28.3 & & \\
\hline Center & 68 & 22.7 & & \\
\hline Center-Right & 44 & 14.7 & & \\
\hline Right & 22 & 7.3 & & \\
\hline Conservative Right & 6 & 2.0 & & \\
\hline \multicolumn{5}{|l|}{ Fiscal Political Views } \\
\hline Liberal Left & 22 & 7.3 & & \\
\hline Left & 42 & 14.0 & & \\
\hline Center-Left & 87 & 29.0 & & \\
\hline Center & 75 & 25.0 & & \\
\hline Center-Right & 41 & 13.7 & & \\
\hline Right & 28 & 9.3 & & \\
\hline Conservative Right & 5 & 1.7 & & \\
\hline
\end{tabular}


Table 1. Cont.

\begin{tabular}{|c|c|c|c|c|}
\hline Variables & $\mathbf{n}$ & $\%$ & $\begin{array}{c}M \\
(\min -\max )\end{array}$ & $S D$ \\
\hline \multicolumn{5}{|l|}{ Social Political Views } \\
\hline Liberal Left & 26 & 8.7 & & \\
\hline Left & 63 & 21.1 & & \\
\hline Center-Left & 80 & 26.8 & & \\
\hline Center & 70 & 23.4 & & \\
\hline Center-Right & 35 & 11.7 & & \\
\hline Right & 20 & 6.7 & & \\
\hline Conservative Right & 5 & 1.7 & & \\
\hline \multicolumn{5}{|l|}{ Religious } \\
\hline Yes & 207 & 68.8 & & \\
\hline No & 94 & 31.2 & & \\
\hline \multicolumn{5}{|c|}{ Frequency of Religious Services Attendance } \\
\hline Never & 42 & 14.5 & & \\
\hline A Few Times & 114 & 39.3 & & \\
\hline Less than Once a Month & 35 & 12.1 & & \\
\hline Once a Month & 19 & 6.6 & & \\
\hline More than Once a Month & 48 & 16.6 & & \\
\hline Once a Week or More & 32 & 11.0 & & \\
\hline \multicolumn{5}{|l|}{ Importance of Religion } \\
\hline None & 23 & 7.7 & & \\
\hline Little & 78 & 26.0 & & \\
\hline Moderate & 160 & 53.3 & & \\
\hline Substantial & 39 & 13.0 & & \\
\hline \multicolumn{5}{|l|}{ Religiosity } \\
\hline None & 62 & 20.8 & & \\
\hline Little & 70 & 23.5 & & \\
\hline Moderate & 128 & 43.0 & & \\
\hline Substantial & 38 & 12.8 & & \\
\hline
\end{tabular}

\subsection{Measurement Instruments}

Sociodemographic questionnaire. This study utilized a sociodemographic questionnaire that allowed for a detailed characterization of the sample. Some examples of the information collected by the questionnaire were age, gender, sexual orientation, level of political interest, political views (general, fiscal, and social), the level of importance attributed to religion, and the frequency of religious services attendance.

The Sexual Prejudice Scale in the Portuguese Political Context (SPSPPC)-Adapted. The Sexual Prejudice Scale in the Portuguese Political Context consists of a translation and adaptation of Baiocco et al.'s (2018) "Sexual Prejudice in Sports Scale" to the Portuguese political context. The original scale assesses negative attitudes and prejudice toward lesbian and gay (LG) individuals in athletic contexts (Baiocco et al. 2018). The Sexual Prejudice Scale in the Portuguese political context assesses negative attitudes and prejudice toward LGB individuals in the Portuguese political context. As in the original scale, each of the 19 items is associated with a 7-point Likert scale, ranging from 1-strongly disagree to 7-strongly agree, with higher scores signifying more negative attitudes and prejudice toward LG people (Baiocco et al. 2018). According to the original scale, the first factor, Open Rejection, consists of seven items and reflects the open prejudice expressed toward LG individuals. The second factor, Denial of Visibility, comprises five items and encompasses attitudes about rejection and the categorical denial of the existence of sexual minorities. Finally, the third factor, Gender Performance, concerns beliefs that poor performance is related to the fact that a person is LG. In order to validate this adaptation to a political context, we chose to perform a three-factor analysis, obtaining a different organization of the items according to the factors. The first factor, Heterosexual Superiority (F1), consists of items $4,8,11,12,13,14,15,16,17$, and 18. These items measure heterosexual individuals' feelings of superiority in relation to LGB individuals. The second factor, LGB Denial (F2), 
encompasses items 1,2,3,5,7,9, and 10. These items relate to the idea that individuals' sexual orientations inherently condition their political participation. The third factor, LGB Invisibility (F3), comprises items 6 and 19 and refers to the idea that sexual orientation should not be openly discussed. Cronbach's alphas were used to measure factor reliability (Factor $1-\alpha=0.930$; Factor $2-\alpha=0.841$; Factor $3-\alpha=0.572$; total SPSPPC score $\alpha=0.903)$. Due to its low reliability, Factor 3 was not considered in the statistical analyses conducted in this study. In order to assess convergent validity, correlation levels of the SPSPPC and the Portuguese version of the Attitudes toward Lesbians and Gay Men Scale (Alves 2018), originally created by Herek (1988), were calculated, obtaining a very strong, positive, and statistically significant correlation coefficient $(\mathrm{r}=0.75 ; p<0.001)$.

\subsection{Procedures}

Initially, the researchers conducted a translation and adaptation of the Sexual Prejudice in Sports Scale by Baiocco et al. (2018) to create the Sexual Prejudice Scale in the Portuguese political context (SPSPPC). This process included a forward translation, an expert panel back-translation, pre-testing, and cognitive interviewing, until researchers obtained a final version of the SPSPPC. The study utilized an online platform to provide participants access to the informed consent waiver, the sociodemographic questionnaire, and the Sexual Prejudice Scale in the Portuguese political context. This platform was then disseminated by e-mail to a total of 4194 people belonging to a range of Portuguese political positions and institutions, namely civil parishes (2757 people), municipalities (1092 people), Portuguese Parliament members (230 people), and members of official political parties (115 people). The response rate was approximately $7.2 \%$. Participants responded to the study outreach online, receiving emails that referred them directly to the online survey where they were informed that their responses would be anonymous and confidential, in accordance with the Declaration of Helsinki-Ethical Principles for Medical Research Involving Human Subjects. The first page of the questionnaire explained the study's objectives and informed participants about how to complete the survey, their freedom to withdraw from the study, and how to contact the authors for further information, if needed.

\section{Results}

This section describes participants' scores for the total SPSPPC scale, as well as Factors 1 and 2, according to their sociodemographic characteristics, such as gender, religiosity, and political orientation. Table 2 shows the average sample scores obtained by the SPSPPC and its factors. Given that the SPSPPC allows for higher possible scores - 7 points-the following theoretical weightings were used in order to classify sexual prejudice levels: 1-3-low, 3-5-moderate, and 5-7-high. Thus, in accordance with this criterion, the average score obtained by the $\operatorname{SPSPPC}(M=2.40 ; S D=0.85)$ can be considered low, as well as the scores for Factor $1(M=1.82 ; S D=0.96)$ and Factor $2(M=2.22 ; S D=1.08)$.

Table 2. Sexual Prejudice Scale in the Portuguese political context (SPSPPC) and Factors 1 and 2 score results.

\begin{tabular}{ccc}
\hline Factors & $\boldsymbol{M}$ (min-max) & $S D$ \\
\hline Sexual Prejudice Scale in the Portuguese & $2.40(1-5.70)$ & 0.85 \\
Political Context & $1.82(1-5.20)$ & 0.96 \\
Factor 1-Heterosexual Superiority & $2.22(1-6.14)$ & 1.08 \\
Factor 2-LGB Denial & \\
\hline
\end{tabular}

\subsection{Results for Sexual Prejudice Levels by Gender}

There were statistically significant differences between men's and women's SPSPPC scores $(t(299)=3.192 ; p=0.002)$, with men scoring higher $(M=2.55 ; S D=0.87)$ than women. The study also found statistically significant differences for F1 $(t(284)=2.537 ; p=0.012)$ and F2 $(t(288)=4.020 ; p=0.000)$, with men showing higher F1 $(M=1.96 ; S D=1.01)$ and F2 scores $(M=2.46 ; S D=1.15)$, as displayed in Table 3 . 
Table 3. Sexual prejudice levels by gender.

\begin{tabular}{|c|c|c|c|c|}
\hline Gender & $M$ & $S D$ & $t(d f)$ & $p$ \\
\hline \multicolumn{5}{|c|}{ Factor 1} \\
\hline Men & 1.96 & 1.01 & \multirow{2}{*}{$2.537(284)$} & \multirow{2}{*}{0.012 * } \\
\hline Women & 1.68 & 0.89 & & \\
\hline \multicolumn{5}{|c|}{ Factor 2} \\
\hline Men & 2.46 & 1.15 & \multirow{2}{*}{$4.020(288)$} & \multirow{2}{*}{$0.000 * *$} \\
\hline Women & 1.96 & 0.94 & & \\
\hline \multicolumn{5}{|c|}{ SPSPPC } \\
\hline Men & 2.55 & 0.87 & \multirow{2}{*}{$3.192(299)$} & \multirow{2}{*}{0.002 * } \\
\hline Women & 2.24 & 0.81 & & \\
\hline
\end{tabular}

\subsection{Results for Sexual Prejudice Levels by Religiosity}

Statistically significant differences were found between religious and non-religious individuals for the SPSPPC $(F(1)=18.746 ; p=0.000), F 1(F(1)=12.071 ; p=0.001)$ and F2 $(F(1)=20.789 ; p=0.000)$. Religious individuals displayed higher scores for $\mathrm{F} 1(M=1.95$; $S D=1.03)$, F2 $(M=2.42 ; S D=1.14)$, and the SPSPPC $(M=2.54 ; S D=0.90)$, as pictured in Table 4.

Table 4. Sexual prejudice levels by religiosity (religious or non-religious).

\begin{tabular}{|c|c|c|c|c|}
\hline Religiosity & $M$ & $S D$ & $t(d f)$ & $p$ \\
\hline & & Factor 1 & \multirow{3}{*}{$12.071(1)$} & \multirow{3}{*}{0.001 * } \\
\hline Religious & 1.95 & 1.03 & & \\
\hline Non-religious & 1.53 & 0.72 & & \\
\hline & & Factor 2 & \multirow{3}{*}{$20.789(1)$} & \\
\hline Religious & 2.42 & 1.14 & & \multirow{2}{*}{$0.000 * *$} \\
\hline Non-religious & 1.82 & 0.80 & & \\
\hline & & PSPPC & & \\
\hline Religious & 2.54 & 0.90 & \multirow{2}{*}{18.746 (298) } & \multirow{2}{*}{$0.000^{* *}$} \\
\hline Non-religious & 2.10 & 0.64 & & \\
\hline
\end{tabular}

\subsection{Results for Sexual Prejudice Levels by General Political Views}

Participants demonstrated statistically significant differences in $\operatorname{SPSPPC}(F(6 ; 292)=$ $3.917 ; p=0.001), \mathrm{F} 1(F(6 ; 277)=2.576 ; p=0.019)$, and F2 $(F(6 ; 281)=4.936 ; p=0.000)$ scores based upon their general political views. Conservative right participants displayed the highest scores for F1 $(M=2.24 ; S D=1.70)$ and F2 $(M=2.76 ; S D=1.73)$, while center-right participants showed the highest SPSPPC scores $(M=2.69 ; S D=0.86)$, as shown in Table 5 .

\subsection{Results for Sexual Prejudice Levels by Fiscal Political Views}

Statistically significant differences were found concerning participants' fiscal political views for the SPSPPC $(F(6 ; 292)=3.194 ; p=0.005), F 1(F(6 ; 278)=2.739 ; p=0.013)$, and F2 $(F(6 ; 281)=3.485 ; p=0.002)$. Participants identifying as holding conservative right political views displayed the highest scores for $\mathrm{F} 1(M=2.48 ; S D=1.87)$ and $\mathrm{F} 2(M=2.86 ; S D=1.90)$. For the SPSPPC, center-right participants scored highest $(M=2.79 ; S D=1.00)$, as shown in Table 6. 
Table 5. Sexual prejudice levels by general political views.

\begin{tabular}{|c|c|c|c|c|}
\hline General Political Views & $M$ & $S D$ & $F(d f)$ & $p$ \\
\hline \multicolumn{5}{|c|}{ Factor 1} \\
\hline Liberal Left & 1.65 & 1.00 & & \\
\hline Left & 1.46 & 0.64 & & \\
\hline Center-Left & 1.77 & 0.96 & & \\
\hline Center & 1.94 & 0.97 & $2.576(6 ; 277)$ & 0.019 * \\
\hline Center-Right & 2.13 & 0.94 & & \\
\hline Right & 2.03 & 1.16 & & \\
\hline Conservative Right & 2.24 & 1.70 & & \\
\hline \multicolumn{5}{|c|}{ Factor 2} \\
\hline Liberal Left & 1.57 & 0.66 & & \\
\hline Left & 1.91 & 0.83 & & \\
\hline Center-Left & 2.10 & 1.08 & & \\
\hline Center & 2.43 & 1.04 & $4.936(6 ; 281)$ & $0.000 * *$ \\
\hline Center-Right & 2.67 & 1.17 & & \\
\hline Right & 2.55 & 1.15 & & \\
\hline Conservative Right & 2.76 & 1.73 & & \\
\hline \multicolumn{5}{|c|}{ SPSPPC } \\
\hline Liberal Left & 1.99 & 0.67 & & \\
\hline Left & 2.12 & 0.65 & & \\
\hline Center-Left & 2.32 & 0.83 & & \\
\hline Center & 2.57 & 0.90 & $3.917(6 ; 292)$ & 0.001 * \\
\hline Center-Right & 2.69 & 0.86 & & \\
\hline Right & 2.67 & 0.91 & & \\
\hline Conservative Right & 2.64 & 1.37 & & \\
\hline
\end{tabular}

Table 6. Sexual prejudice levels by fiscal political views.

\begin{tabular}{|c|c|c|c|c|}
\hline Fiscal Political Views & $M$ & $S D$ & $F(d f)$ & $p$ \\
\hline \multicolumn{5}{|c|}{ Factor 1} \\
\hline Liberal Left & 1.56 & 0.82 & & \\
\hline Left & 1.54 & 0.80 & & \\
\hline Center-Left & 1.74 & 0.92 & & \\
\hline Center & 1.94 & 1.02 & $2.739(6 ; 278)$ & 0.013 * \\
\hline Center-Right & 2.24 & 1.00 & & \\
\hline Right & 1.79 & 0.87 & & \\
\hline Conservative Right & 2.48 & 1.87 & & \\
\hline \multicolumn{5}{|c|}{ Factor 2} \\
\hline Liberal Left & 1.64 & 0.69 & & \\
\hline Left & 1.95 & 0.97 & & \\
\hline Center-Left & 2.10 & 1.04 & & \\
\hline Center & 2.40 & 1.04 & $3.485(6 ; 281)$ & $0.002 *$ \\
\hline Center-Right & 2.65 & 1.20 & & \\
\hline Right & 2.32 & 1.10 & & \\
\hline Conservative Right & 2.86 & 1.90 & & \\
\hline \multicolumn{5}{|c|}{ SPSPPC } \\
\hline Liberal Left & 2.01 & 0.63 & & \\
\hline Left & 2.18 & 0.71 & & \\
\hline Center-Left & 2.31 & 0.83 & & \\
\hline Center & 2.52 & 0.83 & $3.194(6 ; 292)$ & 0.005 * \\
\hline Center-Right & 2.79 & 1.00 & & \\
\hline Right & 2.43 & 0.77 & & \\
\hline Conservative Right & 2.57 & 1.62 & & \\
\hline
\end{tabular}




\subsection{Results for Sexual Prejudice Levels by Social Political Views}

Statistically significant differences were found among participants based upon their social political views for the SPSPPC $(F(6 ; 291)=6.022, p=0.000), \mathrm{F} 1(F(6 ; 276)=3.703$; $p=0.001)$, and F2 $(\mathrm{F}(6 ; 280)=6.195 ; \mathrm{p}=0.000)$. Conservative right participants displayed the highest scores for F1 $(M=2.48 ; S D=1.62), \mathrm{F} 2(M=3.03 ; S D=1.78)$, and the SPSPPC $(M=2.90 ; S D=1.48)$, as seen in Table 7 .

Table 7. Sexual prejudice levels by social political views.

\begin{tabular}{|c|c|c|c|c|}
\hline Social Political Views & $M$ & $S D$ & $F(d f)$ & $p$ \\
\hline \multicolumn{5}{|c|}{ Factor 1} \\
\hline Liberal Left & 1.50 & 0.67 & & \\
\hline Left & 1.50 & 0.75 & & \\
\hline Center-Left & 1.74 & 0.93 & & \\
\hline Center & 2.08 & 1.09 & $3.703(6 ; 276)$ & 0.001 * \\
\hline Center-Right & 2.15 & 0.97 & & \\
\hline Right & 1.91 & 0.94 & & \\
\hline Conservative Right & 2.48 & 1.62 & & \\
\hline \multicolumn{5}{|c|}{ Factor 2} \\
\hline Liberal Left & 1.69 & 0.60 & & \\
\hline Left & 1.83 & 0.87 & & \\
\hline Center-Left & 2.09 & 1.06 & & \\
\hline Center & 2.50 & 1.09 & $6.195(6 ; 280)$ & $0.000 * *$ \\
\hline Center-Right & 2.79 & 1.14 & & \\
\hline Right & 2.54 & 1.15 & & \\
\hline Conservative Right & 3.03 & 1.78 & & \\
\hline \multicolumn{5}{|c|}{ SPSPPC } \\
\hline Liberal Left & 1.95 & 0.55 & & \\
\hline Left & 2.12 & 0.66 & & \\
\hline Center-Left & 2.30 & 0.82 & & \\
\hline Center & 2.64 & 0.88 & $6.022(6 ; 291)$ & $0.000 * *$ \\
\hline Center-Right & 2.86 & 0.95 & & \\
\hline Right & 2.52 & 0.82 & & \\
\hline Conservative Right & 2.90 & 1.48 & & \\
\hline
\end{tabular}

\subsection{Correlational Analysis}

As shown in Table 8, a correlation analysis was conducted to determine levels of association between sexual prejudice and age, education, political interest, political engagement, time in politics, importance of religion, and attitudes toward sexual minorities. Correlation coefficients were all statistically significant $(p<0.001)$ (except for time in politics), especially attitudes toward lesbians and gay men.

Table 8. Results for the correlation matrix between sexual prejudice and other variables.

\begin{tabular}{|c|c|c|c|c|c|c|c|c|}
\hline Variables & 1 & 2 & 3 & 4 & 5 & 6 & 7 & 8 \\
\hline 1-Age & - & & & & & & & \\
\hline 2-Education & 0.170 ** & - & & & & & & \\
\hline 3-Political Interest & -0.049 & $0.273^{* *}$ & - & & & & & \\
\hline 4-Political Engagement & -0.062 & $0.248^{* *}$ & $0.818^{* *}$ & - & & & & \\
\hline 5 -Time in Politics & $0.210^{* *}$ & -0.049 & 0.123 & 0.081 & - & & & \\
\hline 6-Importance of Religion & 0.079 & $-0.150 * *$ & 0.030 & 0.091 & 0.031 & - & & \\
\hline $\begin{array}{c}\text { 7-Attitudes toward Lesbians } \\
\text { and Gay Men }\end{array}$ & $0.335^{* *}$ & $-0.259^{* *}$ & $-0.242^{* *}$ & $-0.282^{* *}$ & 0.125 & $0.247^{* *}$ & - & \\
\hline 8-Sexual Prejudice & $0.198^{* *}$ & $-0.132 *$ & $-0.164^{* *}$ & $-0.224^{* *}$ & 0.068 & $0.195^{* *}$ & $0.725^{* *}$ & - \\
\hline
\end{tabular}




\subsection{Hierarchical Multiple Regression}

Finally, a hierarchical multiple regression analysis was performed to assess the effects of age, education, political interest, political engagement, importance of religion, and attitudes toward lesbians and gay men on sexual prejudice. The possible confounding variables "age", "gender", and "education" were added in the first block. The variables "political interest", "political engagement", "general political views", and "importance of religion" were added in the second block. The variable "Attitudes toward Lesbians and Gay Men" was added in the third block. The first block of the analysis explained $8 \%$ of the overall variance, while the second block explained $22 \%$. The third block explained $54 \%$ Therefore, as shown in Table 9, negative levels of political engagement and negative attitudes toward lesbians and gay men were significant predictors of sexual prejudice.

Table 9. Hierarchical multiple regression analysis predicting sexual prejudice.

\begin{tabular}{|c|c|c|c|c|c|c|c|c|c|}
\hline \multirow[b]{2}{*}{ Variables } & \multicolumn{3}{|c|}{ Model 1} & \multicolumn{3}{|c|}{ Model 2} & \multicolumn{3}{|c|}{ Model 3} \\
\hline & B & SE B & $\beta$ & B & SE B & $B$ & B & SE B & $\beta$ \\
\hline Age & 0.014 & 0.005 & 0.173 * & 0.011 & 0.005 & $0.133 *$ & -0.004 & 0.004 & -0.044 \\
\hline Gender & -0.246 & 0.103 & $-0.144 *$ & -0.332 & 0.100 & $-0.195 *$ & -0.120 & 0.079 & -0.070 \\
\hline Education & -0.094 & 0.058 & -0.099 & -0.005 & 0.057 & -0.005 & 0.050 & 0.045 & 0.053 \\
\hline Political Interest & & & & 0.051 & 0.120 & 0.040 & 0.086 & 0.093 & 0.068 \\
\hline Political Engagement & & & & -0.321 & 0.095 & $-0.309 *$ & -0.148 & 0.075 & -0.142 * \\
\hline General Political Views & & & & 0.095 & 0.034 & $0.162 *$ & -0.009 & 0.027 & -0.015 \\
\hline Importance of Religion & & & & 0.180 & 0.062 & $0.169 *$ & 0.060 & 0.048 & 0.057 \\
\hline $\begin{array}{l}\text { Attitudes toward Lesbians } \\
\text { and Gay Men }\end{array}$ & & & & & & & 0.895 & 0.067 & $0.704^{* *}$ \\
\hline$R^{2}$ & \multicolumn{3}{|c|}{0.080} & \multicolumn{3}{|c|}{0.219} & \multicolumn{3}{|c|}{0.535} \\
\hline F for change in $R^{2}$ & \multicolumn{3}{|c|}{$7.785^{* *}$} & \multicolumn{3}{|c|}{$10.607^{* *}$} & \multicolumn{3}{|c|}{$37.985^{* *}$} \\
\hline
\end{tabular}

\section{Discussion}

This was the first study in Portugal to assess sexual prejudice among politicians. Despite low overall levels of sexual prejudice in the sample, men displayed higher sexual prejudice scores, a finding corroborated by previous studies (Herek 2002, 2009; Kite and Whitley 1996; LaMar and Kite 1998). Since the vast majority of participants self-identified as heterosexual, this may have had a negative impact on their attitudes toward LG people (Adams et al. 2016; Costa et al. 2014; Costa et al. 2018; Keiller 2010). These results suggest that differences in sexual prejudice based on gender are rooted in beliefs regarding gender roles (Bosson et al. 2012; Brown and Henriquez 2008; Costa and Davies 2012). Thus, traditional beliefs associated with gender roles, modern sexism, and hypermasculinity are the most important predictors of sexual prejudice, all of which can be psychologically and socially advantageous for one's sexual identity (Herek 2000a; Lingiardi et al. 2015).

Sexual prejudice scores were significantly higher among religious participants, compared to non-religious participants. These results are in line with other studies that have found that religion represents an important predictor of negative attitudes toward LG people, and which have observed more negative attitudes toward LG people among religious individuals (Duck and Hunsberger 1999; Costa and Salinas-Quiroz 2019; Herek and Capitanio 1996; Rosik et al. 1037). In fact, highly religious people tend to express more negative reactions toward gay and bisexual individuals, for instance, by opposing policies and laws that prohibit employment discrimination against them or laws that allow for same-sex unions or marriage, among others (Brint and Abrutyn 2010; West 2018). In addition, those who oppose same-sex marriage often highlight the damage done to society, families, and children, resulting from the approval of marriage equality for LGBT people (Cowan et al. 2005).

In this study, political views were divided into three categories-general, fiscal, and social. Among all three categories, the highest levels of sexual prejudice were found among those expressing right-wing political views. According to previous research, people 
who hold right-wing and more conservative political positions usually present higher levels of sexual prejudice (Avery et al. 2007; Hoyt et al. 2018; Whitley and Lee 2000), while individuals with more liberal political ideologies typically present lower levels of sexual prejudice (Herek 2000a, 2002; Hoyt et al. 2018; Schwartz 2010). This finding may be explained by the fact that right-wing political positions tend to be more frequently associated with religiousness and traditional beliefs (Costa et al. 2014).

Correlational analysis and hierarchical multiple regression analysis confirm that modern conceptualizations of sexual prejudice in the Portuguese political context are still associated with more traditional forms of heterosexism, even though some participants were likely to express prejudice in other, subtler ways, such as keeping to heteronormative sex and gender roles. Nevertheless, the strong correlations with traditional heterosexism suggest that these factors are useful subtle indicators of attitudes toward lesbians and gay men (Massey 2009). The opposite effect may be found regarding political engagement, since other findings support the theory that more politically engaged politicians tend to show lower perceptions of gender and sexual orientation inequalities (Bernstein 2005).

Some limitations of this study ultimately restrict the generalizability of its findings. Sample participants were disproportionately recruited from civil parishes, in addition to being well-educated and possessing Internet and technological access. It would be useful if future studies could include more members working in higher levels of government, especially members of parliament. Furthermore, the use of complementary methodologies such as in-depth face-to-face interviews or focus groups could be useful in future research.

The researchers hope that the pioneering nature of this study in Portugal will encourage further research on this topic. In addition, this study allowed us to affirm that sexual prejudice is a reality in in the Portuguese political context, in addition to which variables are relevant when studying sexual prejudice. However, as there is no further research concerning this topic, it is pertinent that future studies be carried out to confirm or dispute this study's findings.

Research regarding sexual prejudice is extremely important, not only in the political context itself, but also for the general public. As reported in this study, the sample of selfidentified politicians displayed low levels of sexual prejudice. As these individuals have the power to make decisions, such as passing laws with direct positive or negative impacts on sexual minorities' lives, it is extremely important to raise awareness regarding the prevalence of sexual prejudice in the Portuguese political context, so that it can be reduced or eliminated. At the same time, sharing these results may help citizens to make more informed electoral decisions, as, in many cases, sexual prejudice is subtle and invisible. This study also reinforces the need to reflect upon the implications that this phenomenon may have for sexual minorities, such as employment, rental, and general forms of discrimination, as well as the higher prevalence of mental health disorders (e.g., depression or anxiety), among other issues. Thus, when confronted with this information, individuals, whether politicians or members of the general public, have the opportunity to seek changes to expand equal rights and demand action to achieve this goal.

Author Contributions: Conceptualization, H.P.; Data curation, M.F.; Formal analysis, M.F. and H.P.; Methodology, M.F., H.P.; Writing—original draft, M.F.; Writing—review \& editing, M.F.; H.P. All authors have read and agreed to the published version of the manuscript.

Funding: This research was not funded.

Institutional Review Board Statement: The research was approved by the university research ethics board.

Informed Consent Statement: All subjects gave their informed consent for inclusion before they participated in the study.

Data Availability Statement: The data presented in this study are available upon request.

Conflicts of Interest: The authors declare no conflict of interest. 


\section{References}

Adams, Katherine, Craig Nagoshi, Gabrielle Filip-Crawford, Heather Terrell, and Julie Nagoshi. 2016. Components of gendernonconformity prejudice. International Journal of Transgenderism 17: 185-98. [CrossRef]

Almeida, Miguel. 2010. O contexto LGBT em Portugal. In Estudo sobre a Discriminação em Função da Orientação Sexual e da Identidade de Género. Edited by Nogueira Conceição and João Oliveira. Lisboa: Comissão para a Cidadania e Igualdade de Género, pp. 45-92.

Alves, Regina. 2018. Atitudes dos/as estudantes universitários/as face à homossexualidade: Tradução e validação de uma escala de medida. Educar em Revista 34: 191-204. [CrossRef]

Andersen, Robert, and Tina Fetner. 2008. Cohort differences in tolerance of homosexuality: Attitudinal change in Canada and the United States, 1981-2000. Public Opinion Quarterly 72: 311-30. [CrossRef]

Avery, Alison, Justin Chase, Linda Johansson, Samantha Litvak, Darrel Montero, and Michael Wydra. 2007. America's changing attitudes toward homosexuality, civil unions, and same-gender marriage: 1977-2004. Social Work 52: 71-79. [CrossRef]

Baiocco, Roberto, Jessica Pistella, Marco Salvati, Salvattore Ioverno, and Fabio Lucidi. 2018. Sexual prejudice in sport scale: A new measure. Journal of Homosexuality, 1-24. [CrossRef]

Barth, Jay, and Janine Parry. 2009. Political culture, public opinion, and policy (non)diffusion: The case of gay and lesbian-related issues in Arkansas. Social Science Quarterly 90: 309-25. [CrossRef]

Baunach, Dawn. 2012. Changing same-sex marriage attitudes in America from 1988 through 2010. Public Opinion Quarterly 76: 364-78. [CrossRef]

Bernstein, Arla. 2005. Gendered Characteristics of Political Engagement in College Students. Sex Roles 52: 299-310. [CrossRef]

Bosson, Jennifer, Jonathan Weaver, Andrew Caswell, and Rochelle Burnaford. 2012. Gender threats and men's antigay behaviors: The harmful effects of asserting heterosexuality. Group Processes $\mathcal{E}$ Intergroup Relations 15: 471-86. [CrossRef]

Brewer, Paul, and Clyde Wilcox. 2005. Same-sex marriage and civil unions. Public Opinion Quarterly 69: 599-616. [CrossRef]

Brint, Steven, and Seth Abrutyn. 2010. Who's right about the right? Comparing competing explanations of the link between white evangelicals and conservative politics in the United States. Journal for the Scientific Study of Religion 49: 328-50. [CrossRef]

Brown, Michael, and Ernesto Henriquez. 2008. Socio-demographic predictors of attitudes towards gays and lesbians. Individual Differences Research 6: 193-202.

Brumbaugh, Stacey, Laura Sanchez, Steven Nock, and James Wright. 2008. Attitudes toward gay marriage in states undergoing marriage law transformation. Journal of Marriage and Family 70: 345-59. [CrossRef]

Burridge, Joseph. 2004. I am not homophobic but ... Disclaiming in discourse resisting repeal of section 28. Sexualities 7: 327-44. [CrossRef]

Carneiro, Nuno, and Isabel Menezes. 2007. From an oppressed citizenship to affirmative identities. Journal of Homosexuality 53: 65-82. [CrossRef]

Carroll, Aengus, and Lucas Mendos. 2017. State-Sponsored Homophobia 2017: A World Survey of Sexual Orientation Laws: Criminalisation, Protection and Recognition. International Lesbian Gay Bisexual Trans and Intersex Association. Available online: http://ilga.org/downloads/2017/ILGA_State_Sponsored_Homophobia_2017_WEB.pdf (accessed on 17 November 2020).

Costa, Pedro, and Michelle Davies. 2012. Portuguese adolescents' attitudes toward sexual minorities: Transphobia, homophobia, and gender role beliefs. Journal of Homosexuality 59: 1424-42. [CrossRef]

Costa, Pedro, and Fernando Salinas-Quiroz. 2019. A comparative study of attitudes toward same-gender parenting and gay and lesbian rights in Portugal and in Mexico. Journal of Homosexuality 66: 1909-26. [CrossRef]

Costa, Pedro, Sara Caldeira, Inês Fernandes, Cláudia Rita, Henrique Pereira, and Isabel Leal. 2014. Religious and political conservatism and beliefs about same-sex parenting in Portugal. Psychology, Community \& Health 3: 23-35. [CrossRef]

Costa, Pedro, Henrique Pereira, and Isabel Leal. 2018. Through the lens of sexual stigma: Attitudes toward lesbian and gay parenting. Journal of GLBT Family Studies, 1-18. [CrossRef]

Cowan, Gloria, Becky Heiple, Carolyn Marquez, Désireé Khatchadourian, and Michelle McNevin. 2005. Heterosexuals' attitudes toward hate crimes and hate speech against gays and lesbians: Old-fashioned and modern heterosexism. Journal of Homosexuality 49: 67-82. [CrossRef]

Duck, Robert, and Bruce Hunsberger. 1999. Religious orientation and prejudice: The role of religious proscription, right-wing. International Journal for the Psychology of Religion 9: 157-79. [CrossRef]

Fernandes, Jorge, and Pedro Magalhães. 2020. The 2019 Portuguese general elections. West European Politics 43: 1038-50. [CrossRef]

Haslam, Nick, and Sheri Levy. 2006. Essentialist beliefs about homosexuality: Structure and implications for prejudice. Personality and Social Psychology Bulletin 32: 471-85. [CrossRef]

Herek, Gregory. 1988. Heterosexuals' attitudes toward lesbians and gay men: Correlates and gender differences. Journal of Sex Research 25: 451-77. [CrossRef]

Herek, Gregory. 2000a. Sexual prejudice and gender: Do heterosexuals' attitudes toward lesbians and gay men differ? Journal of Social Issues 56: 251-66. [CrossRef]

Herek, Gregory. 2000b. The psychology of sexual prejudice. Current Directions in Psychological Science 9: 19-22. [CrossRef]

Herek, Gregory. 2002. Gender gaps in public opinion about lesbians and gay men. Public Opinion Quarterly 66: 40-66. [CrossRef]

Herek, Gregory. 2009. Sexual prejudice. In Handbook of Prejudice, Stereotyping, and Discrimination. Edited by Nelson Todd. New York: Psychology Press, pp. 441-67. 
Herek, Gregory, and John Capitanio. 1996. "Some of my best friends" intergroup contact, concealable stigma, and heterosexuals' attitudes toward gay men and lesbians. Personality and Social Psychology Bulletin 22: 412-24. [CrossRef]

Herek, Gregory, and Kevin McLemore. 2013. Sexual Prejudice. Annual Review of Psychology 64: 309-33. [CrossRef]

Herek, Gregory, J. Roy Gillis, and Jeanine Cogan. 2009. Internalized stigma among sexual minority adults: Insights from a social psychological perspective. Journal of Counseling Psychology 56: 32-43. [CrossRef]

Hoyt, Crystal, and Mitchell Parry. 2018. Sociocultural and individual manifestations of sexual stigma: The role of political ideology and prejudice in discrimination against sexual minorities. Journal of Social and Political Psychology 6: 2195-3325. [CrossRef]

Hoyt, Crystal, Thekla Morgenroth, and Jeni Burnette. 2018. Understanding sexual prejudice: The role of political ideology and strategic essentialism. Journal of Applied Social Pshychology. [CrossRef]

Huffaker, Laena, and Paul Kwon. 2016. A comprehensive approach to sexual and transgender prejudice. Journal of Gay E Lesbian Social Services 28: 195-213. [CrossRef]

Keiller, Scott. 2010. Masculine norms as correlates of heterosexual men's attitudes toward gay men and lesbian women. Psychology of Men E Masculinity 11: 38-52. [CrossRef]

Kite, Mary, and Bernard Whitley. 1996. Sex differences in attitudes toward homosexual persons, behaviors, and civil rights: A meta-analysis. Personality and Social Psychology Bulletin 22: 336-53. [CrossRef]

LaMar, Lisa, and Mary Kite. 1998. Sex differences in attitudes toward gay men and lesbians: A multidimensional perspective. Journal of Sex Research 35: 189-96. [CrossRef]

Lax, Jeffrey, and Justin Phillips. 2009. Gay rights in the States: Public opinion and policy responsiveness. American Political Science Review 103: 367-86. [CrossRef]

Lewis, Gregory. 2003. Black-white differences in attitudes toward homosexuality and gay rights. Public Opinion Quarterly 67: 59-78. [CrossRef]

Lingiardi, Vittorio, Nicola Nardelli, Salvattore Ioverno, Simona Falanga, Carlo Di Chiacchio, Annalisa Tanzilli, and Roberto Baiocco. 2015. Homonegativity in Italy: Cultural issues, personality characteristics, and demographic correlates with negative attitudes toward lesbians and gay men. Sexuality Research and Social Policy 13: 95-108. [CrossRef]

Lopes, Diniz, João Oliveira, Conceição Nogueira, and Rita Grave. 2016. The social determinants of polymorphous prejudice against lesbian and gay individuals: The case of Portugal. Sexuality Research and Social Policy 14: 56-70. [CrossRef]

Massey, Sean. 2009. Polymorphous Prejudice: Liberating the Measurement of Heterosexuals' Attitudes toward Lesbians and Gay Men. Journal of Homosexuality 56: 147-72. [CrossRef]

Miceli, Melinda. 2005. Morality politics vs. identity politics: Framing processes and competition among christian right and gay social movement organizations. Sociological Forum 20: 589-612. [CrossRef]

Olson, Laura, Wendy Cadge, and Jason Harrison. 2006. Religion and Public Opinion about Same-Sex Marriage. Social Science Quarterly 87: 340-60. [CrossRef]

Poteat, V. Paul, and Ethan Mereish. 2012. Ideology, prejudice, and attitudes toward sexual minority social policies and organizations. Political Psychology 33: 211-24. [CrossRef]

Rosik, Christopher, Lois Griffith, and Zanaida Cruz. 1037. Homophobia and conservative religion: Toward a more nuanced understanding. American Journal of Orthopsychiatry 77: 10-19. [CrossRef] [PubMed]

Schwartz, Joseph. 2010. Investigating differences in public support for gay rights issues. Journal of Homosexuality 57: 748-59. [CrossRef]

Webb, Stephanie, and Jill Chonody. 2014. Heterosexual attitudes toward same-sex marriage: The influence of attitudes toward same-sex parenting. Journal of GLBT Family Studies 10: 404-21. [CrossRef]

West, Keon. 2018. Understanding and reducing sexual prejudice in Jamaica: Theoretical and practical insights from a severely anti-gay society. The Journal of Sex Research, 1-14. [CrossRef]

Whitley, Bernard. 2009. Religiosity and attitudes toward lesbians and gay men: A meta-analysis. International Journal for the Psychology of Religion 19: 21-38. [CrossRef]

Whitley, Bernard, and Sarah Lee. 2000. The relationship of authoritarianism and related constructs to attitudes toward homosexuality. Journal of Applied Social Psychology 30: 144-70. [CrossRef]

Wood, Peter, and John Bartkowski. 2004. Attribution style and public policy attitudes toward gay rights. Social Science Quarterly 85: 58-74. [CrossRef] 